\title{
A new bioassay of VIP: results in watery diarrhoea syndrome
}

\author{
M C LABURTHE,* C M DUPONT, J D BESSON, M ROUSSET, AND \\ G E ROSSELIN
}

From the Unité de Recherches de Diabétologie et d'Etudes Radio-Immunologiques des Hormones Protéiques and Groupe de Recherches sur l'Immunologie de la Différenciation, INSERM, Paris, France

SUMMARY Cyclic AMP accumulation in human colon adenocarcinoma cells in culture (HT-29) is known to be particularly sensitive to the stimulating action of vasoactive intestinal peptide (VIP). This property was exploited as a means of investigating the possible role of VIP as a humoral mediator in the watery diarrhoea syndrome. Our results showed that plasma from two patients with watery diarrhoea syndrome associated with ganglioneuroblastoma and pheochromocytoma strongly stimulated cyclic AMP accumulation in HT-29 cells, whereas plasma from normal subjects and patients with other diarrhoeal disorders had no effect. The stimulation induced by serial dilutions of plasma from patients paralleled the VIP-induced response. Preincubation of these plasmas with specific anti-VIP antibody prevented their stimulatory effects. Plasma sampled after the arrest of diarrhoea (spontaneous or after surgical resection of tumours) elicited no cyclic AMP rise in HT-29 cells. Tumour extract stimulated cyclic AMP accumulation in HT-29 cells with a dose-response curve which was superimposable on the one obtained with standard VIP. The results lend support to the hypothesis that VIP is a humoral mediator in WDS and suggest that the diarrhoea is mediated through a VIP-induced accumulation of cyclic AMP in intestinal epithelial cells.

The watery diarrhoea syndrome, as first described by Verner and Morrison ${ }^{1}$ is characterised by a refractory severe watery diarrhoea with hypokalaemia and achlorhydria, and is associated with tumours of the pancreas. Subsequently, reports from other workers ${ }^{2} 3$ showed that several types of tumours were involved and that vasoactive intestinal peptide (VIP) was the humoral mediator responsible for this syndrome. VIP was thought to be involved because immunoreactive VIP-like material was detected in plasma and in tumours from patients with the watery diarrhoea syndrome. A controversy surrounds this hypothesis. ${ }^{4-6}$ VIP nonetheless remains a good candidate as the humoral mediator in the watery diarrhoea syndrome, as it is a highly potent stimulator of intestinal fluid and electrolytes secretion by the intestine ${ }^{7-9}$ and is the sole peptide known to possess high affinity receptors and to stimulate cyclic AMP accumulation in intestinal epithelial cells. ${ }^{10-14}$

In this study, we take advantage of the pronounced

*Address for correspondence and requests for reprints: Marc C Laburthe, Era no. 494 du CRNS, Bâtiment INSERM, Hôpital SaintAntoine, 75571 Paris Cedex 12, France.

Received for publication 7 February 1980 sensitivity of the human colon adenocarcinoma cell line HT-29 to VIP (eliciting cyclic AMP accumulation $^{15}$ ) as the basis for a bioassay for this peptide. We hoped that this experimental approach would enable us to determine whether the plasma of patients with WDS contains VIP: the plasma and tumour extracts from two patients were examined.

\section{Methods}

\section{PATIENTS}

Patient LE was a girl who developed intractable diarrhoea at the age of 2 years, 8 months and was admitted to hospital three months later. Diarrhoea was abundant and aqueous and accompanied by severe hypokalaemia $(1.4 \mathrm{mM} / \mathrm{l})$. Chest ganglioneuroblastoma was rapidly diagnosed by $x$-ray examination and the considerable increase of urinary dopamine $(4.03 \mathrm{mg} / 24 \mathrm{~h})$. The two first determinations of plasma VIP levels were performed when diarrhoea was present. The third determination was done 15 days after spontaneous arrest of this symptom. The other plasma VIP level measurements were performed two days and nine days after resection of the tumour. Histolo- 
gical examination confirmed that the tumour was a ganglioneuroblastoma.

Patient BL, a 42 year old man, was admitted to hospital in February 1978 for evaluation of diarrhoea associated with weight loss and insulin-dependent diabetes mellitus dating from July 1976. Diarrhoea was not improved by anti-diarrhoeal therapy and was first attributed to diabetes, which needed treatment by insulin. The existence of a high plasma VIP level (radioimmunoassay: $\operatorname{Dr} \mathrm{S}$ R Bloom) associated with high urinary elimination of vanilylmandelic acid led to exploration of the adrenals. Angiography and scanner examination showed a tumour of the right adrenal that appeared at histological examination to be a pheochromocytoma. After operation the diarrhoea and diabetes disappeared. The two plasma samples which were tested were obtained one month before and one week after surgery.

These patients were perhaps atypical in not having pancreatic tumours. VIP has, however, been reported in the tissues where their tumours developed-that is, sympathetic nervous system $^{16}$ and adrenal gland. ${ }^{17}$

PLASMA SAMPLING

Blood was collected in a syringe rinsed with heparin, containing kallikrein inhibitor $(500 \mathrm{KIU} / \mathrm{ml}$ of blood) and immediately centrifuged at $4^{\circ} \mathrm{C}$. Plasma were stored at $-20^{\circ} \mathrm{C}$ until the time of assay.

EXTRACTION OF VIP FROM TUMOUR

The ganglioneuroblastoma from patient LE was resected, the tumour boiled immediately for three minutes in water and VIP extracted according to our usual method. ${ }^{18}$

\section{RADIOIMMUNOASSAY OF VIP}

The concentration of VIP in the tumour was assessed by a radioimmunoassay developed in our laboratory. ${ }^{19}$ This assay is highly specific: there is no cross-reaction with glucagon and gastric inhibitory polypeptide and secretin exhibits only $1 / 300$ crossreactivity. The antibody used recognises the VIP that is present in the peripheral ${ }^{19}$ and central ${ }^{20}$ nervous system, but does not take into account the VIP-like substance that has been described in endocrine cells of intestinal epithelium. ${ }^{21}$ Indeed, VIP was undectable in acidic extracts of epithelial cells isolated from rat $^{19}$ and human ${ }^{22}$ intestine when the $\mathrm{ZO}$ antibody was used in the radioimmunoassay. The values obtained with serial dilutions of the tumour extract were superimposable with the standard curve obtained with porcine VIP, thus enabling the VIP content of the tumour extract to e expressed as porcine VIP equivalent.
BIOASSAY OF VIP

Plasma and tumour extracts were tested for their ability to stimulate cyclic AMP accumulation in a human colon adenocarcinoma cell line in culture, HT-29. This cell line was established by Fogh and Trempe ${ }^{23}$ and had previously been shown to have a cyclic AMP system which would respond to VIP at concentrations as low as $3 \times 10^{-12} \mathrm{M}$ VIP.15 The incubation procedure has been detailed elsewhere. ${ }^{15}$ Cells $\left(10^{6} / \mathrm{ml}\right)$ were incubated for 30 minutes at $15^{\circ} \mathrm{C}$ in Krebs Ringer phosphate buffer, $\mathrm{pH} 7.5$ containing $2 \%(\mathrm{w} / \mathrm{v})$ bovine serum albumin and $0.2 \mathrm{mM}$ 3-isobutyl-1-methylxanthine. Cyclic AMP was measured in cells plus medium by a radioimmunoassay procedure. ${ }^{15}$

We tested whether VIP was responsible for the plasma-induced stimulation of cyclic AMP production by employing a specific anti-VIP antibody. ${ }^{19}$ Plasmas were tested either alone or after a 12 hour-exposure at $4^{\circ} \mathrm{C}$ to excess antibody $\mathrm{ZO}$ that is, at the final dilution of $1 / 40$. Exposure of plasma from patients $B L$ and $L E$, or porcine VIP to the same dilution of normal rabbit serum did not abolish their stimulating effect.

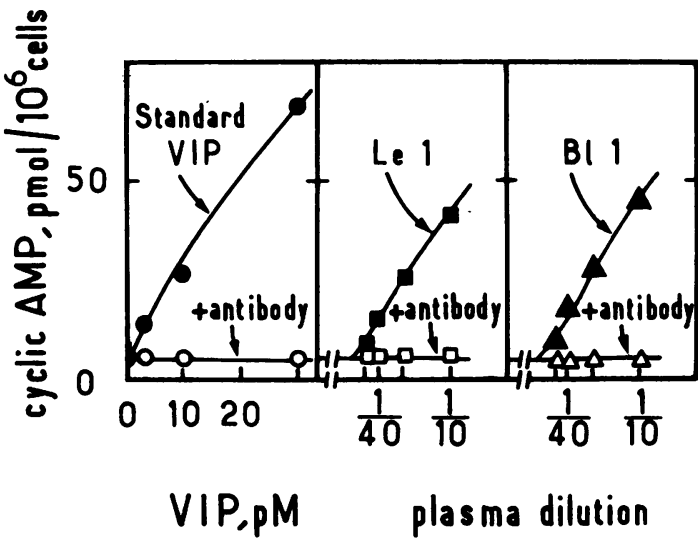

Fig. 1 Effect (closed symbols) of native porcine VIP (left panel) and plasma from patient $L E$ (middle panel) and BL (right panel) on cyclic AMP accumulation in HT-29 cells. Previous exposure of standard VIP or plasma to anti-VIP antibody (open symbols) was conducted as indicated in the Methods section. Plasmas were tested at four dilutions $(1 / 10,1 / 20,1 / 40,1 / 80)$ as indicated. Incubation conditions were described in the Methods section. Each point is the mean of triplicate determinations.

\section{Results}

Figure 1 shows that plasmas from two patients with the watery diarrhoea syndrome (BL and LE) stimulated cyclic AMP accumulation in HT-29 
cells. These stimulations depended on the dilution of plasma: dilution curves paralleled the doseresponse of porcine VIP which was used as the standard. A significant stimulation was still obtained with plasma diluted 40 -fold. With the lowest dilution tested (10 times), plasma BL and LE, respectively elicited a nine and eight-fold increase of cyclic AMP above basal levels. Plasmas from five normal subjects, tested at the same dilution, did not induce any significant change in the basal cyclic AMP level (not shown). The stimulation was confirmed to be due to VIP in studies where plasmas from these patients were preincubated with the anti-VIP anti-serum ZO (see Methods section): the preincubation completely abolished the stimulating effect (Fig. 1). A similar preincubation of standard VIP with anti-VIP antiserum likewise suppressed the stimulation induced by the standard (Fig. 1).

Serial sampling of plasma during the follow-up of patients showed that there was a close correlation between the occurrence of clinical signs - that is, diarrhoea and hypokalaemia-and the stimulating effect of plasma on cyclic AMP accumulation in HT-29 cells (Table). Indeed, for both patients the arrest of diarrhoea after surgery was associated with the absence of any stimulating effect of their plasmas. It is noteworthy that the spontaneous arrest of diarrhoea that occurred before surgery in patient LE was also associated with a lack of stimulation. If it is assumed that VIP is the sole molecule responsible for the stimulation (Fig. 1), then the plasma VIP concentrations during diarrhoea can be calculated as being in the range between 90 and $180 \mathrm{pM}$. The plasma levels of VIP after the arrest of diarrhoea and in normal subjects not suffering from diarrhoea were below $30 \mathrm{pM}$. Plasmas from patients with other diarrhoeal disorders (three with ulcerative colitis, two with Crohn's disease, one with alpha chain disease and two children with milk protein intolerance or acute viral diarrhoea) were taken as controls. None of them elicited any significant effect in altering cyclic AMP levels in HT-29 cells.

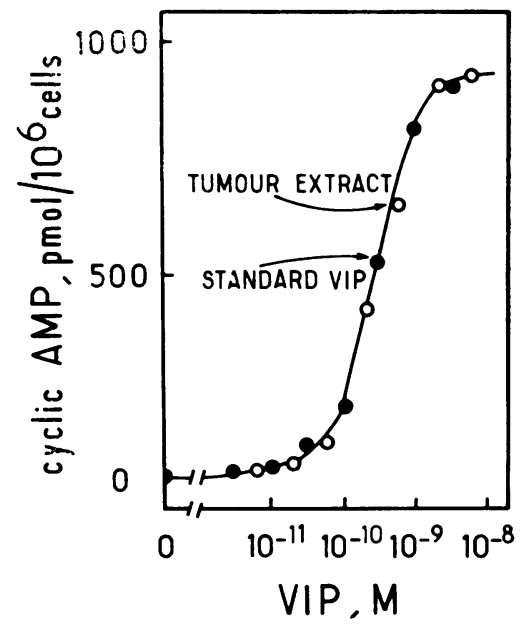

Fig. 2 Effect of tumour extract on cyclic AMP accumulation in HT-29 cells. The tumour extract was obtained as indicated in the Methods section.

Concentrations of human VIP in the tumour extract were measured by a specific radioimmunoassay (see Methods section). Each point is the mean of triplicate determinations.

Figure 2 shows the stimulation of cyclic AMP accumulation in HT-29 cells induced by acidic extracts of the tumour from patient LE. On the basis of the VIP content of tumour extract, as measured by radioimmunoassay, ${ }_{19}$ the dose-response curve obtained with tumour extract was superimposable on the one obtained with standard VIP.

\section{Discussion}

The nature of the humoral mediator responsible for the diarrhoea in the watery diarrhoea syndrome had remained controversial up till now. ${ }^{4-6} \mathrm{~A}$ role of VIP in this disease had been initially suggested from radioimmunological measurements: high levels of VIP were found in the plasma. ${ }^{23}$ However,

Table Correlation between occurrence of clinical signs and stimulating effect of plasma on cyclic AMP accumulation in HT-29 cells

\begin{tabular}{|c|c|c|c|c|}
\hline Patient & Sample & Clinical signs* & $\begin{array}{l}\text { Cyclic AMP accumulation in } \\
H T-29 \text { cells }(\% \text { of basal) }\end{array}$ & Plasma VIP concentration ( $p M)$ \\
\hline BL & $\begin{array}{l}1 \\
2 \ddagger\end{array}$ & + & $\begin{array}{c}920 \pm 30 \S \\
90 \pm 20 \dagger\end{array}$ & $\begin{array}{l}180 \pm 10 \S \\
<30\end{array}$ \\
\hline LE & $\begin{array}{l}1 \\
2 \\
3 \\
4+ \\
5+\end{array}$ & $\begin{array}{l}+ \\
+ \\
-\end{array}$ & $\begin{array}{l}830 \pm 40 \\
490 \div 20 \\
190 \pm 40 \dagger \\
150 \pm 40 \dagger \\
150 \pm 40 \dagger\end{array}$ & $\begin{array}{c}150 \pm 20 \\
90 \pm 10 \\
<30 \\
<30 \\
<30\end{array}$ \\
\hline
\end{tabular}


several authors ${ }^{45}$ found that these observations needed to be interpreted with caution, as most of the VIP radioimmunoassays were very insensitive and gave a wide range of normal plasma values. Moreover, the presence of high VIP levels in plasma from patients does not necessarily imply that VIP is involved in the genesis of diarrhoea. Only the demonstration of a direct effect of VIP on intestinal epithelium could settle this point.

The present paper demonstrates that plasmas from two patients with the watery diarrhoea syndrome stimulate cyclic AMP accumulation in HT-29 cells. To our knowledge, this is the first report to show that plasmas of patients with the watery diarrhoea syndrome are able to evoke a biological response in human intestinal epithelial cells. The response was abolished by preincubating the plasmas with anti-VIP immunserum (Fig. 1), thus suggesting that the substance responsible for the effect was VIP. Additional evidence for the involvement of VIP was provided by the measurement of identical amounts of VIP in the tumour extract using either a specific radioimmunoassay or the ability of the extract to stimulate cyclic AMP production in HT-29 cells (Fig. 2).

The transformed cell line HT-29 was found to be highly suitable for these studies. The marked cyclic AMP response of HT-29 cells to VIP ${ }^{15}$ constituted the basis for a highly sensitive bioassay for VIP and enabled the detection of the peptide in plasmas diluted as much as 40-fold (Fig. 1). One could, of course, question whether physiological conclusions can be drawn from studies performed with a mutant cell line. We know, however, that the affinity and the specificity of VIP receptors in HT-29 cells and in normal intestinal epithelial cells are identical. ${ }^{11}$ Furthermore, we have recently been able to confirm that the plasma used in this study also evoked a significant cyclic AMP response in epithelial cells from normal human intestine:22 the response was lower than in HT-29 cells. If one accepts that cyclic AMP is involved in the secretory response of the intestine, ${ }^{24} 25$ one can reasonably propose that the plasma from patients with the watery diarrhoea syndrome induces the accumulation of cyclic AMP in their intestinal epithelial cells and that this represents the initial event in the manifestation of the watery diarrhoea.

Both immunological and biological criteria thus led us to conclude that VIP is probably a mediator of the watery diarrhoea syndrome, at any rate in the two cases investigated. This does not, however, rule out the involvement of other humoral mediators in other cases, ${ }^{26}{ }^{27}$ particularly in view of the fact that many different types of tumours have been incriminated in the genesis of this syndrome. ${ }^{23}$
This work was supported by the Institut National de la Santé et de la Recherche Médicale (Grant ASR no. 2), by the Délégation Générale à la Recherche Scientifique et Technique (Grant no. 79 7 0775), and by the Centre National de la Recherche Scientifique. Porcine VIP was a generous gift from Professor V Mutt (Karolinska Institute, Stockholm, Sweden) through the Gastrointestinal Hormones Resources Committee of the National Institute of Arthritis, Metabolism and Digestive Diseases, USA.

\section{References}

${ }^{1}$ Verner JV, Morrison AB. Islet cell tumor and a syndrome of refractory watery diarrhea and hypokalemia. Am J Med 1958; 25: 374-80.

${ }^{2}$ Bloom SR, Polak JM, Pearse AGE. Vasoactive intestinal peptide and watery diarrhea syndrome. Lancet 1973; 2: 14-6.

${ }^{3}$ Said SI, Faloona GR. Elevated plasma and tissue levels of vasoactive intestinal peptide in the waterydiarrhea syndrome due to pancreatic, bronchogenic and other tumors. $N$ Engl J Med 1975; 293: 155-60.

${ }^{4}$ Gardner JD. The VIP controversy. Am J Digest Dis 1978; 23: 370-3.

${ }^{5}$ Strauss E. Radioimmunoassay of gastrointestinal hormones. Gastroenterology 1978; 74: 141-152.

${ }^{6} \mathrm{Jaffe}$ BM. To be or not to VIP. Gatroenterology 1979; 76: 417-20.

${ }^{7}$ Barbezat GD, Grossman MI. Intestinal secretion: stimulation by peptides. Science 1971; 174: 422-4. ${ }^{8}$ Krejs GJ, Barkley RM, Read NW, Fordtran JS. Intestinal secretion induced by vasoactive intestinal polypeptide. A comparison with cholera toxin in the canine jejunum in vivo $J$ Clin Invest $1978 ; 61$ : 1337-45. ${ }^{9}$ Modlin IM, Bloom SR, Mitchell SJ. Experimental evidence for vasoactive intestinal peptide as the cause of the watery diarrhea syndrome. Gastroenterology 1978; 75 : 1051-4.

${ }^{10}$ Laburthe M, Besson J. Bon Hoa DH, Rosselin G. Récepteurs du peptide intestinal vasoactif (VIP dans les entérocytes: laison spécifique et stimulation de l'AMPc cyclique. CR Acad Sci Paris $[D]$ 1977; 284: $2139-42$.

${ }^{11}$ Laburthe M, Bataille D, Rousset M, et al.: The expression of cell surface receptors for VIP, secretin and glucagon in normal and transformed cells of the digestive tract. In: Nicholls P, Moller JV, Jorgensen PL, Moody AJ, eds. Membrane proteins (Proceedings of the 11th FEBS Meeting), Pergamon Press, Oxford and New York: 1978; 271-290.

${ }^{12}$ Laburthe M, Prieto JC, Amiranoff B, Dupont C, Hui Bon Hoa D, Rosselin G. Interaction of vasoactive intestinal peptide with isolated intestinal epithelial cells from rat. II-Characterization and structural requirements of the stimulatory effect of vasoactive intestinal peptide on production of adenosine $3^{\prime}: 5^{\prime}-$ monophosphate. Eur J Biochem 1979; 96: 239-48.

${ }^{13}$ Amiranoff B, Laburthe M, Dupont C, Rosselin G. Characterization of a vasoactive intestinal peptide- 
sensitive adenylate cyclase in rat intestinal epithelial cell membranes. Biochim Biophys Acta 1978; 544: 474-81.

${ }^{14}$ Prieto JC, Laburthe M, Rosselin G. Interaction of vasoactive intestinal peptide with isolated intestinal epithelial cells from rat. I-Characterization, quantitative aspects and structural requirements of binding sites. Eur J Biochem 1979; 96: 229-37.

${ }^{15}$ Laburthe M, Rousset M, Boissard C, Chevalier G, Zweibaum A, Rosselin G. Vasoactive intestinal peptide: a potent stimulator of adenosine $3^{\prime}: 5^{\prime}$-cyclic monophosphate accumulation in gut carcinoma cell lines in culture. Proc Natl Acad Sci USA 1978; 75: 2772-5.

${ }^{16}$ Hokfelt T, Elfvin LG, Schultzberg M, et al.: Immunohistochemical evidence of vasoactive intestinal polypeptide-containing neurons and nerve fibers in sympathetic ganglia. Neuroscience 1977; 2: 885-96.

${ }^{17}$ Besson J, Rotsztejn W, Ruberg M. Involvement of VIP in neuroendocrine functions in the rat. In: Rosselin $\mathrm{G}$, et al. Hormone receptors in digestion and nutrition, Amsterdam, Elsevier/North Holland Biomedical Press: 1979, 457-64.

${ }^{18}$ Laburthe M, Bataille D, Rosselin G.: Vasoactive intestinal peptide (VIP): variation of the jejuno-ileal content in developing rat as measured by radioreceptorassay. Acta Endocr 1977; 84: 588-99.

${ }^{19}$ Besson J, Laburthe M, Bataille D, Dupont C, Rosselin G. Vasoactive intestinal peptide (VIP): tissue distribution in the rat as measured by radioimmunoassay and radioreceptorassay. Acta Endocr 1978; 87: 799-810.

${ }^{20}$ Besson J, Rotsztejn W, Laburthe M, et al. Vasoactive intestinal peptide (VIP): brain distribution, subcellular localization and effect of deafferentation of the hypothalamus in male rats. Brain Res 1979; 165: 79-85. ${ }^{21}$ Polak JM, Pearse AGE, Garaud JC, Bloom SR. Cellular localization of vasoactive intestinal peptide in the mammalian and avian gastrointestinal tract. Gut 1974; 15: 720-4.

${ }^{22}$ Dupont C, Laburthe M, Broyart JP, Bataille D, Rosselin G. Cyclic AMP production in isolated colonic epithelial crypts: a highly sensitive model for the evaluation of vasoactive intestinal peptide action in human intestine. Eur J Clin Invest 1980; 10: 67-76.

${ }^{23} \mathrm{Fogh} \mathbf{J}$, Trempe C. New human tumor cell lines In: Fogh J, ed. Human tumor cells in vitro, New York and London, Plenum Press: 1975, 115-54.

${ }^{24}$ Field M. Intestinal secretion. Gastroenterology 1974; 66: 1063-84.

${ }^{25}$ Strewler GJ, Orloff J. Role of cyclic nucleotides in the transport of water and electrolytes. Adv Cyclic Nucleotide Res 1977; 8: 311-61.

${ }^{26} \mathrm{Jaffe}, \mathrm{BM}$, Condon S.: Prostaglandins $\mathrm{E}$ and $\mathrm{F}$ in endocrine diarrheagenic syndromes. Ann Surg 1976; 184: 516-24.

${ }^{27}$ Sanzenbacher LJ, Mekhjian HS, King DR, Zollinger RM. Studies on the potential role of secretin in the islet cell tumor diarrheogenic syndrome. Ann Surg 1972; 176: 394-402. 